\title{
Analisa Keruntuhan Bendungan Malahayu Kabupaten Brebes Dengan Aplikasi HEC-RAS dan Perhitungan Kerugian Dengan Aplikasi InaSAFE
}

\author{
Adhitya Zein Muammar ${ }^{1 *}$, Pitojo Tri Juwono', Runi \\ Asmaranto ${ }^{1}$ \\ ${ }^{1}$ Jurusan Teknik Pengairan, Fakultas Teknik, Universitas Brawijaya \\ Jln. MT Haryono 167 Malang 65145 Indonesia \\ *Korespondensi Email: adhityazein@ gmail.com
}

Abstract: In the simulation using HEC-RAS 5.0.7 the part to be simulated is the condition of the Malahayu Dam which collapsed due to 7 conditions causing inundation in the downstream area of the Malahayu Dam. Obtained from 7 conditions of the dam collapse, the overtopping collapse scenario is the most extreme collapse scenario with an inundation area of $143.54 \mathrm{~km} 2$ with a maximum flood inundation height of $19.943 \mathrm{~m}$. The purpose of this dam collapse simulation is to get the most extreme inundation so that in the next process of the inundation, the calculation of economic losses will be carried out with the help of the InaSAFE application. Losses resulting from the Malahayu Dam collapse scenario cover 53 villages from 6 subdistricts so that the evacuation victims reached 22400 people. With this amount, it can be determined that the Malahayu Dam is a dam with a hazard level 4, which is very high. The estimated losses incurred as a result of this collapse reached Rp. $515,521,114,788$. The purpose of this study is to determine the level of danger of a dam, to know the characteristics of the flood, and to know the losses caused by flooding due to dam collapse.

Keywords: Dam Break, InaSAFE, Malahayu Dam, Overtopping, Piping.

Abstrak: Dalam simulasi menggunakan HEC-RAS 5.0.7 bagian yang akan disimulasikan adalah kondisi Bendungan Malahayu yang runtuh diakibatkan oleh 7 kondisi sehingga menyebabkan genangan pada daerah hilir Bendungan Malahayu. Didapatkan dari 7 kondisi keruntuhan bendungan skenario keruntuhan overtopping merupakan skenario keruntuhan paling ekstrim dengan luas genangan mencapai $143,54 \mathrm{~km}^{2}$ dengan tinggi genangan banjir maksimum mencapai 19,943 m. Tujuan dari simulasi keruntuhan bendungan ini untuk mendapat genangan paling ekstrim sehingga pada proses selanjut dari genangan tersebut akan dilakukan proses perhitungan kerugian ekonomi dengan bantuan aplikasi InaSAFE. Kerugian yang dihasilkan dari skenario keruntuhan Bendungan Malahayu meliputi 53 desa dari 6 kecamatan sehingga korban evakuasi mencapai 22400 jiwa. Dengan jumlah tersebut dapat ditentukan bahwa Bendungan Malahayu merupakan bendungan dengan tingkat 
bahaya tingkat 4 yaitu sangat tinggi. Estimasi kerugian yang ditanggung akibat keruntuhan ini mencapai Rp. 515.521.114.788. Tujuan dari studi ini adalah mengetahui tingkat bahaya sebuah bendungan, mengetahui karakteristik banjir, serta mengetahui kerugian yang ditimbulkan dari banjir akibat keruntuhan bendungan.

Kata kunci: Bendungan Malahayu, InaSAFE, Keruntuhan Bendungan, , Overtopping, Piping,

\section{Pendahuluan}

Salah satu sumber kehidupan yang mutlak diperlukan oleh makhluk hidup, baik itu manusia, hewan, atau tumbuhan adalah air [1]. Bendungan dibangun guna mendapatkan manfaat yang signifikan bagi manusia tetapi pembangunannya juga berpotensi menimbulkan bahaya yang sangat besar jika terjadi keruntuhan. Dampak yang terjadi akibat keruntuhan tersebut berupa bencana serta kerusakan yang teradi di hilir. Dengan berdirinya suatu bendungan maka perkembangan di daerah hilir juga berpengaruh pada semakin pesatnya jumlah penduduk yang ada, hal ini menyebabkan makin bertambahnya tingkat bahaya akibat keruntuhan bendungan [2].

Suatu bendungan yang di bangun akan memiliki banyak keuntungan yang bisa di manfaatkan. Menurut PP no 37 Tahun 2010 fungsi bendungan adalah sebagai penyedia air baku, irigasi dll. Diketahui bahwa sebuah tampungan air yang besar (waduk), yang memiliki kegunaan sebagai tangkapan air pada musim hujan dan sebagai penyimpanan di musim kemarau yang dimanfaatkan untuk banyak hal salah satunya untuk irigasi, selain itu bendungan juga memiliki factor ancaman bahaya apabila bendungan itu runtuh atau mengalami kegagalan. Paada suatu konstruksi bendungan sangat penting untuk memliki stabilitas konstruksi yang baik [3].

Tujuan dari penelitian ini adalah mengetahui karakteristik banjir akibat keruntuhan bendungan, mengetahui tingkat bahaya Bendungan Malahayu, serta mengetahui berapa besarnya estimasi kerugian yang ditimbulkan dari runtuhnya bendungan. Sehingga apabila bendungan ini runtuh dapat diminimalisir kerugiannya baik kerugian secara materil maupun non materil.

\section{Bahan dan Metode}

\subsection{Bahan}

Dalam studi ini dibutuhkan data guna menunjang studi kali ini, data yang butuhkan adalah sebagai berikut:

a. Data Hujan

Data hujan yang digunakan selama 13 tahun mulai dari tahun 2007 - 2019. Data hujan ini selanjutnya akan digunakan untuk analisis hidrologi mulai dari uji kualitas data sampai Flood Routing.

b. Data Teknis Bendungan

Data teknis Bendungan Malahayu contohnya berupa tinggi bendungan, kapasitas bendungan, dan dimensi bendungan.

c. Peta Isohyet Jawa Tengah

Peta ini beguna sebagai pembanding untuk menentukan nilai hujan PMP (Probable Maximum precipitation) yang akan digunakan, dimana apabila hujan PMP hitung > hujan PMP peta maka akan menggunakan nilai dari PMP hitung untuk perhitungan selanjutnya, begitu pula sebaliknya.

d. Peta DEM (Data Elevation Model)

Digunakan untuk penggambaran kondisi bagian hilir bendungan pada software HEC-RAS

e. Peta Rupa Bumi (RBI) 
Peta ini beguna untuk melakukan overlay saat output banjir dari HEC-RAS sudah ada, sehingga dapat mengetahui desa mana saja yang terdampak oleh banjir dari hasil keruntuhan bendungan.

f. Data jumlah penduduk

Data ini berguna sebagai data acuan jumlah penduduk yang terdampak pada sebuah wilayah yang terdampak oleh banjir. Data yang digunakan adalah jumlah penduduk pada tahun 2020

g. Data OSM (Open Street Map)

Data berbentuk SHP (Shape File) untuk memudahkan analisis dalam InaSAFE yang terdiri dari data OSM bangunan, jalan, landuse, dan Penduduk.

\subsection{Metode}

Sebelum data dipakai di perhitungan debit banjir rencana dan hujan rencana, seri data debit banjir maksimum sesaat atau seri data hujan yang harian maksimum ini harus diuji dengan analisis outler dan analisis kecenderungan (trend) [4]. Kemudian melakukan perhitungan hujan rerata daerah. Selanjutnya melakukan perhitungan analisa frekuensi dengan metode Log Pearson III dan Metode Gumbel. Hasil analisa frekuensi tersebut perlu diuji menggunakan uji kesesuaian distribusi dengan Metode Chi-Square dan Metode Smirnov-Kolmogorov. Selanjutnya menghitung hujan PMP (Probable Maximum Precipitation). Kemudian menghitung distribusi hujan jam - jaman dengan Metode PSA 007 dan analisis hidrologi berakhir pada perhitungan hidrograf satuan sintetis (HSS) dengan membandingkan Metode Nakayasu dan Metode Limantara yang akan digunakan adalah metode hidrograf satuan sintetis dengan nilai paling tinggi.

Setelah memiliki nilai hidrograf satuan sintetis perhitungan dilanjutkan dengan melakukan penelusuran banjir melewati pelimpah dengan $\mathrm{Q}_{1000}$ dan $\mathrm{Q}_{\mathrm{PMF}}$. Tujuan dari penelusuran banjir ini untuk mengetahui apakah debit inflow dengan $\mathrm{Q}_{1000}$ dan $\mathrm{Q}_{\mathrm{PMF}}$ bendungan mengalami overtopping apa tidak. Setelah melakukan penelusuran banjir maka dilakukan simulasi keruntuhan bendungan dengan bantuan aplikasi HEC-RAS dengan 7 skenario dan dipilih 1 skenario yang sangat ekstrim untuk perhitungan kerugian.

Selanjutnya setelah mendapat sebaran banjir yang terekstrim, dilanjutkan dengan perhitungan kerugian dengan bantuan aplikasi InaSAFE.

\subsection{Persamaan}

\subsubsection{Analisis Frekuensi}

Tujuan dari sebuah analisa frekuensi data hidrologi ialah mencari hubungan antara besarnya kejadian ekstrim terhadap frekuensi kejadian dengan memakai distribusi probabilitas.

2.3.1.1 Log Pearson III

The Hydrology Commite of the Water Resourcess Council, USA menganjurkan dalam menghitung banjir rencana pertama kali mentransportasikan data ke nilai logaritma, lalu hitung parameter statistiknya karena transformasi tersebut, maka cara ini disebut dengan nama Log Pearson III [5].

\subsubsection{Gumbel}

$$
\log x=\overline{\log X}+K . S d \quad \text { Pers. } 1
$$

Pada distribusi gumbel atau disebut distribusi ekstrim tipe I biasanya digunakan pada analisis data maksimum, seperti pada analisis frekuensi banjir, persoalan paling tua adalah berhubungan dengan nilai nilai ekstrim yang datang dari persoalan banjir.

\subsubsection{Uji Kesesuaian Distribusi}

$$
X=\bar{X}+S d . K \quad \text { Pers. } 2
$$

data hidrologi yang dipakai untuk mengestimasi banjir rancangan (design flood) ataupun debit andalan (dependable discharge ) menggunakan analisis frekuensi belum tentu sesuai dengan distribusi - distribusi yang dipilih. Untuk itu perlu dilakukan uji kesesuaian distribusi. Ada 2 uji yang bisa dilakukan dalam hal ini yaitu uji Smirnov-Kolmogorov dan uji Chi Square [6]. 


\subsubsection{Debit Banjir Rencangan}

\subsubsection{Berdasarkan Hidrograf}

Hidrograf satuan digunakan dalam analisis menentukan banjir rancangan jika data yang tersedia merupakan data hujan. Metode ini relatif sederhana, mudah penerapannya, data yang diperlukan sederhana, dan hasil rancangan yang diberikan cukup teliti [7].

Rumus HSS Nakayasu:

$$
\begin{array}{lll}
\text { Qp } & =\frac{1}{3,6}\left[\frac{\text { CA } . \mathrm{R}_{0}}{0,3 \mathrm{TP}+\mathrm{T}_{0,3}}\right] & \text { Pers. 3 } \\
\operatorname{tg} & =0,4+0,058 \mathrm{~L} \rightarrow \text { untuk } \mathrm{L}>15 \mathrm{~km} & \text { Pers. } 4 \\
\operatorname{tg} & =0,21 \mathrm{~L}^{0,7} \rightarrow \text { untuk } \mathrm{L}<15 \mathrm{~km} & \text { Pers. 5 } \\
\mathrm{T}_{0,3} & =\alpha \cdot \operatorname{tg} \text { Pers. } 4 & \text { Pers. 6 } \\
\operatorname{tr} & =0,5 \operatorname{tg} \text { sampai } 1 \mathrm{tg} & \text { Pers. 7 } \\
\mathrm{Tp} & =\operatorname{tg}+0,8 \mathrm{tr} & \text { Pers. 8 }
\end{array}
$$$$
\operatorname{tg} \quad=0,21 \mathrm{~L}^{0,7} \rightarrow \text { untuk } \mathrm{L}<15 \mathrm{~km} \quad \text { Pers. } 5
$$$$
\begin{array}{lll}
\operatorname{tr} & =0,5 \text { tg sampai } 1 \text { tg } & \text { Pers. } 7
\end{array}
$$

dengan:

$\operatorname{tg} \quad=$ waktu konsentrasi (jam)

$\mathrm{L} \quad=$ panjang sungai utama $(\mathrm{km})$

$\mathrm{T}_{0,3} \quad$ = waktu dari puncak banjir sampai 0,3 kali debit puncak (jam)

tr $\quad=$ satuan waktu dari curah hujan (jam)

$\alpha=$ koefisien karakteristik DAS atau parameter hidrograf

$\mathrm{Tp}=$ waktu dari permulaan banjir sampai puncak hidrograf (jam)

Qp = debit puncak banjir $\left(\mathrm{m}^{3} / \mathrm{det}\right)$

$\mathrm{CA}=$ luas DAS $\left(\mathrm{km}^{2}\right)$

$\mathrm{R}_{0} \quad=$ hujan satuan atau hujan efektif (mm)

Rumus Limantara:

$$
\mathrm{Qp}=0,042 \mathrm{~A}^{0,451} \mathrm{~L}^{0,497} \mathrm{Lc}^{0,356} \mathrm{~S}^{-0,131} \mathrm{n}^{0,168} \quad \text { Pers. } 9
$$

dengan:

Qp = debit puncak banjir hidrograf satuan $\left(\mathrm{m}^{3} / \mathrm{dt} / \mathrm{mm}\right)$

A $\quad=$ luas DAS $\left(\mathrm{km}^{2}\right)$

$\mathrm{L} \quad=$ panjang sungai utama $(\mathrm{km})$

Lc = panjang sungai dari outlet sampai titik terdekat dengan titik berat DAS $(\mathrm{km})$

$\mathrm{S} \quad=$ kemiringan sungai utama

$\mathrm{n} \quad=$ koefisien kekasaran DAS ;

$$
\mathrm{n}: 0,035(1+\mathrm{Af} / \mathrm{A}) \quad \text { Pers. } 10
$$

Af = luas hutan

$0,042=$ koefisien untuk konversi satuan $\left(\mathrm{m}^{0,25} / \mathrm{dt}\right)$

2.3.4 Keruntuhan Bendungan

Costa melaporkan bahwa untuk bendungan tipe urugan, 35\% terjadi karena overtopping, 38\% karena piping, 21\% ketidak sempurnaan pondasi, dan 6\% disebabkan karena hal lainnya [8]. Proses keruntuhan bendungan akibat overtopping ditunjukan gambar 1 sedangkan keruntuhan bendungan akibat piping ditunjukan oleh gambar 2. 


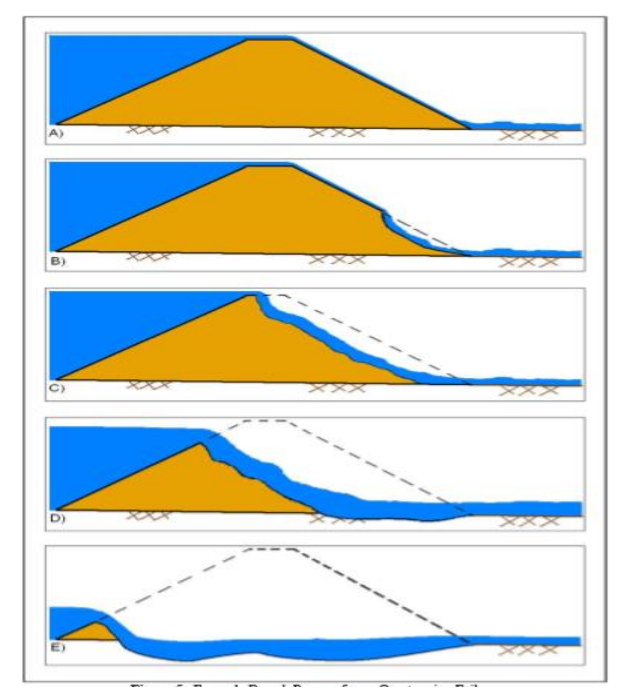

Gambar 1 : Proses Keruntuhan Bendungan Akibat Overtopping

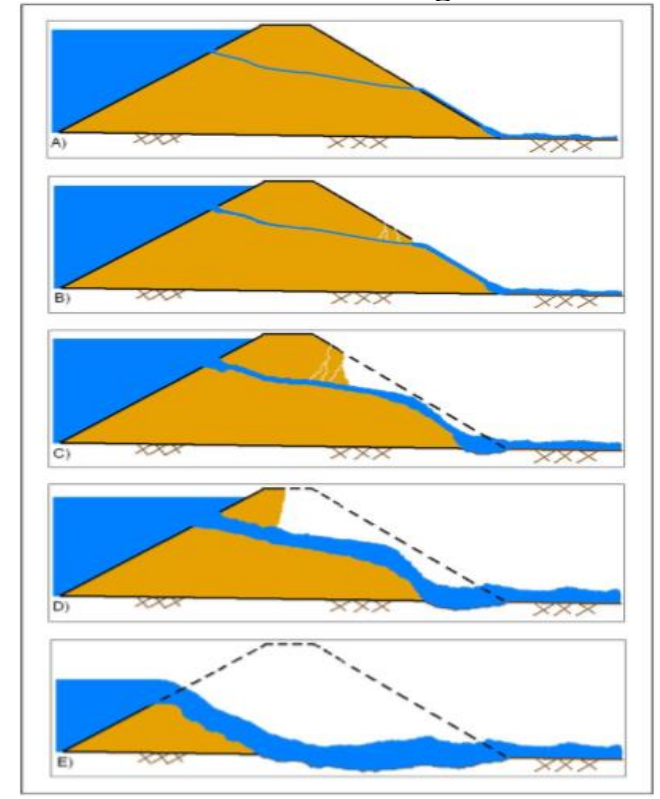

Gambar 2 : Proses Keruntuhan Bendungan Akibat Piping

\subsubsection{Software HEC-RAS}

HEC-RAS (Hydrologic Engineering Center's River Analysis System) adalah perangkat lunak yang memungkinkan untuk melakukan simulasi hidrolik aliran satu dimensi, melakukan perhitungan aliran sungai tidak seragam satu atau dua dimensi, melakukan model pergerakan sedimen dalam aliran tidak seragam dan aliran tidak seragam penuh, melakukan analisis suhu air, dan melakukan pemodelan kualitas air secara umum.

Dalam membuat model hidrolik dengan HEC-RAS memiliki 5 langkah utama yaitu memulai proyek baru, memasukan data geometri, memasukan data aliran dan kondisi batas, melakukan perhitungan hidrolik dan mencetak hasil.

\subsubsection{Klasifikasi Tingkat Bahaya Bendungan}

Dalam Pedoman Teknis Klasifikasi Bahaya Bendungan, kelas bahaya bendungan dibagi menjadi empat kelas, yaitu:

1. Tingkat bahaya rendah

2. Tingkat bahaya sedang

3. Tingkat bahaya tinggi 
4. Tingkat bahaya sangat tinggi

Penetapan kelas atau tingkat kelas didasarkan pada jumlah PenRis (penduduk terkena risiko, yaitu penduduk atau orang-orang yang berada di daerah genangan banjir). PenRis merupakan seluruh penduduk di daerah hilir bendungan yang terancam bahaya jika terjadi keruntuhan bendungan. PenRis dihitung sebagai jumlah kumulatif penduduk terancam

bahaya di seluruh bagian daerah hilir bendungan. PenRis dapat diidentifikasi dari peta genangan hasil studi dari keruntuhan bendungan. Tingkat bahaya bendungan didapatkan dari hubungan antara jumlah PenRis dalam jiwa atau KK ( $1 \mathrm{KK}=5$ orang) dan jarak lokasi PenRis dari bendungan

Tabel 1 : Matriks Jumlah Penduduk (Orang) Terkena Risiko Keruntuhan Bendungan Untuk Masing-masing Kelas Bahaya Bendungan

\begin{tabular}{cccccc}
\hline Jumlah & \multicolumn{5}{c}{ Jarak dari Bendungan (km) } \\
\cline { 2 - 6 } $\begin{array}{c}\text { PenRis } \\
\text { (Orang) }\end{array}$ & $0-$ & $0-$ & $0-$ & $0-$ & $0-$ \\
(Kumulatif) & 5 & 10 & 20 & 30 & $>30$ \\
\hline \hline 0 & 1 & 1 & 1 & 1 & 1 \\
$1-100$ & 3 & 3 & 2 & 2 & 2 \\
$101-1000$ & 4 & 4 & 4 & 3 & 3 \\
$>1000$ & 4 & 4 & 4 & 4 & 4 \\
\hline Sumber: Dept. PU Dirjen Pengairan (2011, p.7)
\end{tabular}

Penentuan tingkat kelas berbasis pada Jumlah PenRis (penduduk terkena resiko). PenRis merupakan semua penduduk di daerah hilir bendungan yang terancam bahaya apabila keruntuhan bendungan terjadi [9].

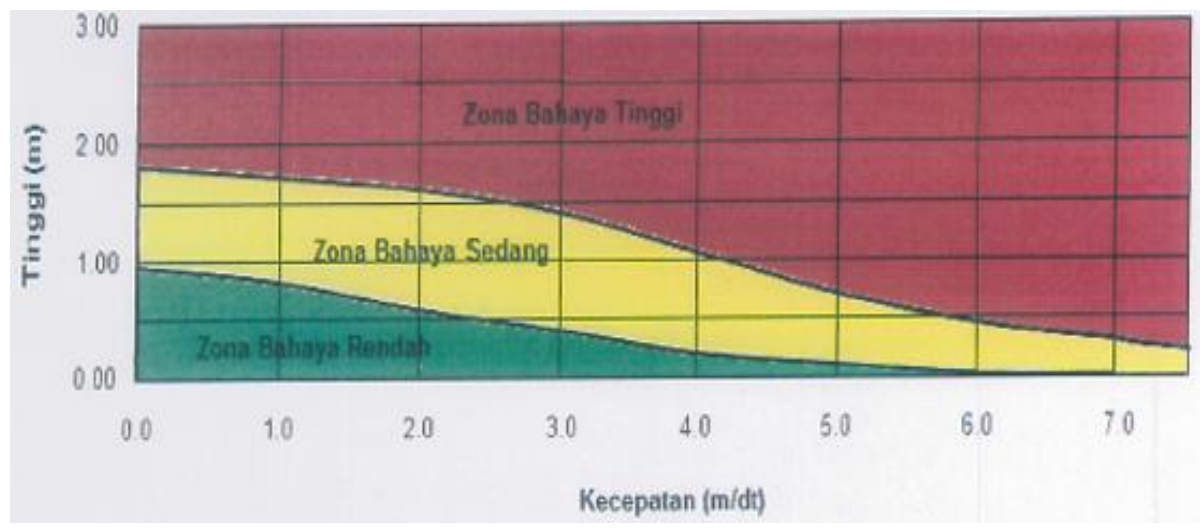

\section{Gambar 3 : Tinggi dan Kecepatan Aliran Banjir yang Berbahaya untuk Hunian}

Terdapat pula tingkat zona bahaya akibat keruntuhan bendungan, yang dibagi menjadi 3 zona berdasarkan ketinggian dan kecepatan banjir, yaitu:
Zona 1 : Zona bahaya rendah
Zona 2 : Zona bahaya sedang
Zona 3 : Zona bahaya tinggi

\section{Hasil dan Pembahasan}

\subsection{Analisis Hidrologi}

Kemungkinan hujan maksimum (PMP) secara teoritis dapat didefinisikan sebagai ketebalan hujan maksimum untuk lama waktu tertentu yang secara fisik mungkin terjadi dalam suatu wilayah aliran dalam kurun waktu tertentu. Kata "kemungkinan" dimaksudkan untuk menekankan bahwa karena proses fisik yang berlangsung di atmosfer kurang begitu dimengerti dan adanya keterbatasan data iklim maka menjadi tidak mungkin untuk menentukan besarnya hujan maksimum dengan ketelitian tinggi [10]. 
Tabel 2 : Perhitungan PMP Metode Hersfield

\begin{tabular}{|c|c|c|c|}
\hline No & Tahun & $\begin{array}{l}\text { hujan } \\
\text { maks }\end{array}$ & $\begin{array}{l}\mathrm{P} \text { setelah } \\
\text { diurutkan }\end{array}$ \\
\hline & & \multicolumn{2}{|c|}{ (mm/hari) } \\
\hline$\overline{11}$ & 2009 & $\overline{173}$ & 80 \\
\hline 2 & 2018 & 137 & 83 \\
\hline 3 & 2019 & 80 & 84 \\
\hline 4 & 2012 & 125 & 90 \\
\hline 5 & 2017 & 141 & 96 \\
\hline 6 & 2016 & 90 & 99 \\
\hline 7 & 2013 & 120 & 120 \\
\hline 8 & 2014 & 124 & 124 \\
\hline 9 & 2010 & 126 & 125 \\
\hline 10 & 2015 & 99 & 126 \\
\hline 11 & 2008 & 96 & 137 \\
\hline 12 & 2011 & 83 & 141 \\
\hline \multirow[t]{7}{*}{13} & 2007 & 84 & 173 \\
\hline & jumlah n & & 1477,85 \\
\hline & rata rata $n$ & & 113,68 \\
\hline & $\mathrm{Sd}$ & & 27,84 \\
\hline & jumlah $n-1$ & & 1304,85 \\
\hline & rata rata $n-1$ & & 108,74 \\
\hline & $\mathrm{Sd} \mathrm{n} \mathrm{-} 1$ & & 22,34 \\
\hline
\end{tabular}

Xn terkoreksi $=\mathrm{Xn}+\mathrm{Km} . \mathrm{Sn}$

$$
\begin{aligned}
& =113,68+1,06 \times 1,04 \\
& =125,32 \mathrm{~mm}
\end{aligned}
$$

Nilai PMP kemudian dikalikan factor pengali untuk durasi 24 jam sebesar 0,9595. PMP

$$
\begin{aligned}
& =493,69 \times 0,9595 \\
& =473,70 \mathrm{~mm} / \mathrm{hari}
\end{aligned}
$$

Berdasarakan nilai PMP Isohyet Wilayah Kabupaten Brebes, PMP yang terjadi di lokasi Bendungan Malahayu sebesar $600 \mathrm{~mm}$. karena nilai PMP hitung lebih kecil dibandingkan dengan PMP peta maka perhitungan selanjutnya menggunakan PMP peta yaitu sebesar $600 \mathrm{~mm}$.

Tabel 3 : Rekapitulasi Nilai Hidrograf Satuan Sintesis

\begin{tabular}{ccc}
\hline \multirow{2}{*}{$\begin{array}{c}\text { Metode } \\
\text { HSS }\end{array}$} & \multicolumn{2}{c}{$\begin{array}{c}\text { Debit Banjir } \\
\text { Rancangan }\left(\mathrm{m}^{3} / \mathrm{dt}\right) \\
\text { dengan kala ulang } \\
\text { tertentu }\end{array}$} \\
\cline { 2 - 3 } & $\begin{array}{c}\text { 1000 th } \\
\text { PMF }\end{array}$ \\
\hline \hline Nakayasu & 583,3237 & 1174,609 \\
Limantara & 551,3406 & 1123,491 \\
\hline
\end{tabular}

Dari table tersebut dapat diketahui bahwa nilai HSS Nakayasu lebih besar dari HSS Limantara dengan $\mathrm{Q} 1000=583,32 \mathrm{~m}^{3} / \mathrm{dt}$ dan $\mathrm{Q}_{\mathrm{PMF}}=1174,61 \mathrm{~m}^{3} / \mathrm{dt}$

\subsection{Penelusuran Banjir Melewati Pelimpah}

Pengertian "Routing banjir melalui waduk" menunjukan operasi dari perhitungan kemungkinan akibat yang terjadi di waduk dengan adanya hidrograf banjir [11]. Penelusuran banjir melalui pelimpah dimaksudkan untuk mengetahui tinggi muka air di atas mercu pelimpah saat suatu debit bajnir melewati 
pelimpah. Dalam analisis keruntuhan bendungan, hasil dari penelusuran banjir tersebut dijadikan dasar dalam penentuan dari kondisi suatu bendungan, apakah suatu bendungan mengalami overtopping atau tidak.

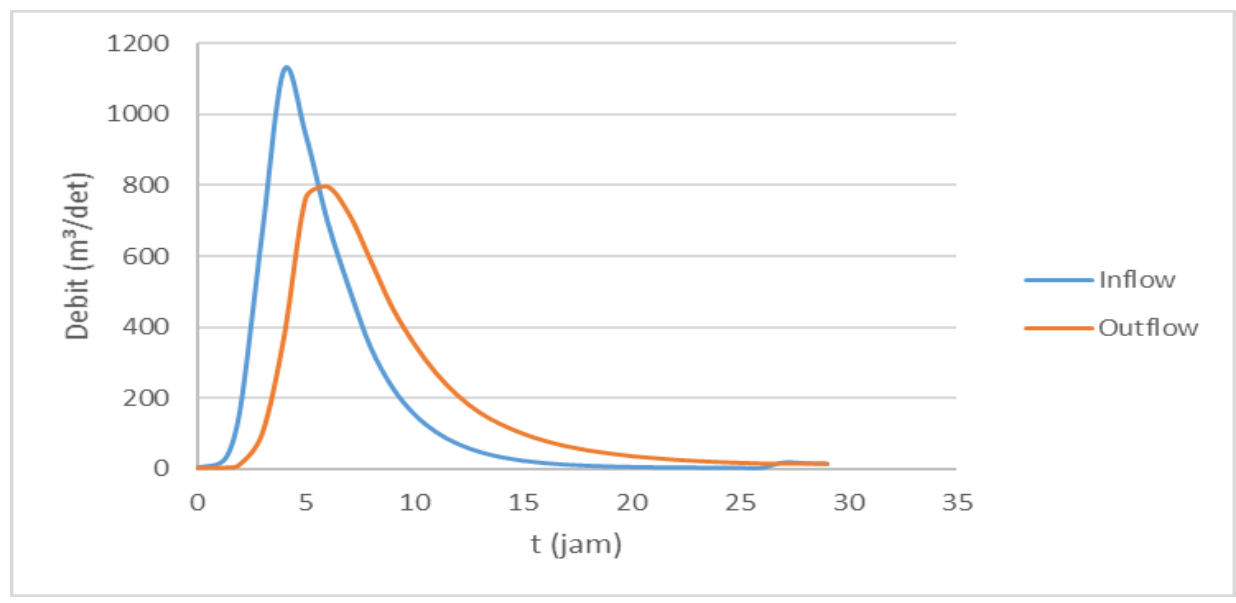

Gambar 4 : Grafik Hubungan Inflow dan Outflow pada pelimpah

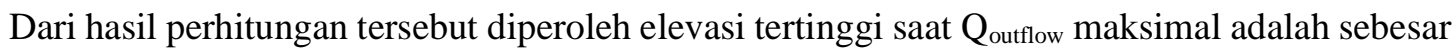
$+60,366$ sedangkat elevasi puncak bendungan adalah $+59,25$. Kondisi overtopping adalah kondisi suatu bendungan dimana air melimpah di atas tubuh bendungan. Hal ini menunjukkan bahwa Bendungan Malahayu mengalami overtoping akibat debit PMF.

\subsection{Analisis Keruntuhan Bendungan Malahayu Menggunakan HEC-RAS.}

Terdapat beberapa kondisi pada analisis keruntuhan bendungan dalam Pedoman Rencana Tindak Darurat Bendungan 2013:

- Cuaca cerah.

- Muka air waduk setinggi puncak bendungan (overtopping)

- Muka air waduk setinggi banjir desain.

Dari tabel tersebut, maka analisis keruntuhan Bendungan Malahayu akan dilakukan sebanyak 7 kondisi. Dimana dalam analisis selanjutnya, akan dicari kondisi yang paling besar.

Parameter keruntuhan bendungan dengan menggunakan rumus Froehlich (2008).

Contoh perhitungan untuk kondisi overtopping

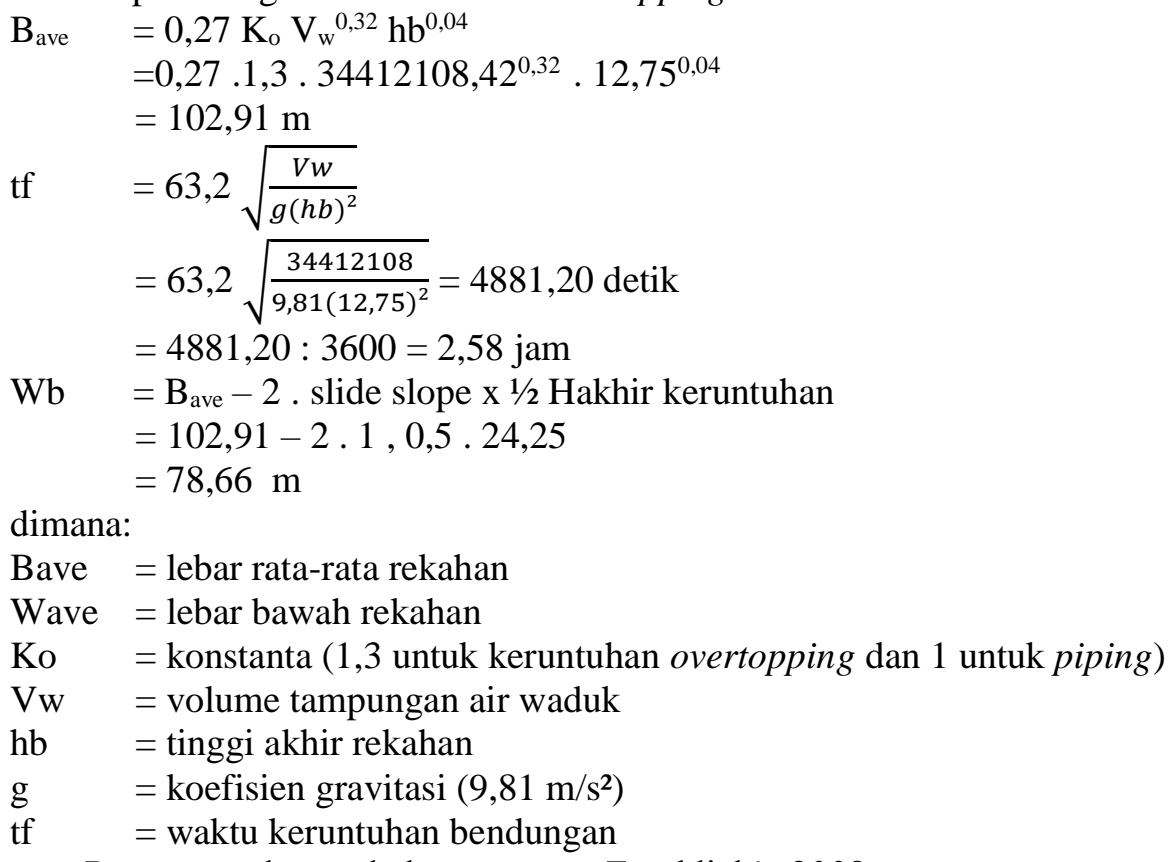

Parameter slope rekahan menurut Froehlich's 2008 
$1 \mathrm{H}: 1 \mathrm{~V}=$ keruntuhan akibat overtopping

$0,7 \mathrm{H}: 1 \mathrm{~V}=$ keruntuhan akibat piping

\subsection{Output Simulasi Program HEC-RAS}

Karakteristik banjir akibat keruntuhan Bendungan Malahayu berbeda untuk setiap kejadian. Karakteristik banjir dapat dilihat dari gambar sebaran itu sendiri atau juga dapat dilihat dengan membuat garis cross section atau long section pada sebaran banjir di menu RAS-Mapper

Tabel 4 : Luas Genangan Banjir Akibat Keruntuhan Bendungan Malahayu

\begin{tabular}{cccc}
\hline Kejadian keruntuhan & Luas $\left(\mathrm{m}^{2}\right)$ & Luas (Ha) & Luas $\left(\mathrm{Km}^{2}\right)$ \\
\hline \hline Overtopping & 143541586,70 & $14.354,16$ & 143,54 \\
Piping atas MAB & 143037376,04 & $14.303,74$ & 143,04 \\
Piping tengah MAB & 141994901,81 & $14.199,49$ & 141,99 \\
Piping bawah MAB & 141961491,91 & $14.196,15$ & 141,96 \\
Piping atas MAN & 141769832,42 & $14.176,9$ & 141,77 \\
Piping tengah MAN & 140881104,71 & $14.088,11$ & 140,88 \\
Piping bawah MAN & 140750570,25 & $14.075,06$ & 140,75 \\
\hline
\end{tabular}

- Dari tabel tersebut diketahui bahwa keruntuhan Bendungan Malahayu akibat overtopping mengakibatkan luasan genangan banjir yang paling tinggi dengan kondisi keruntuhan lainnya.

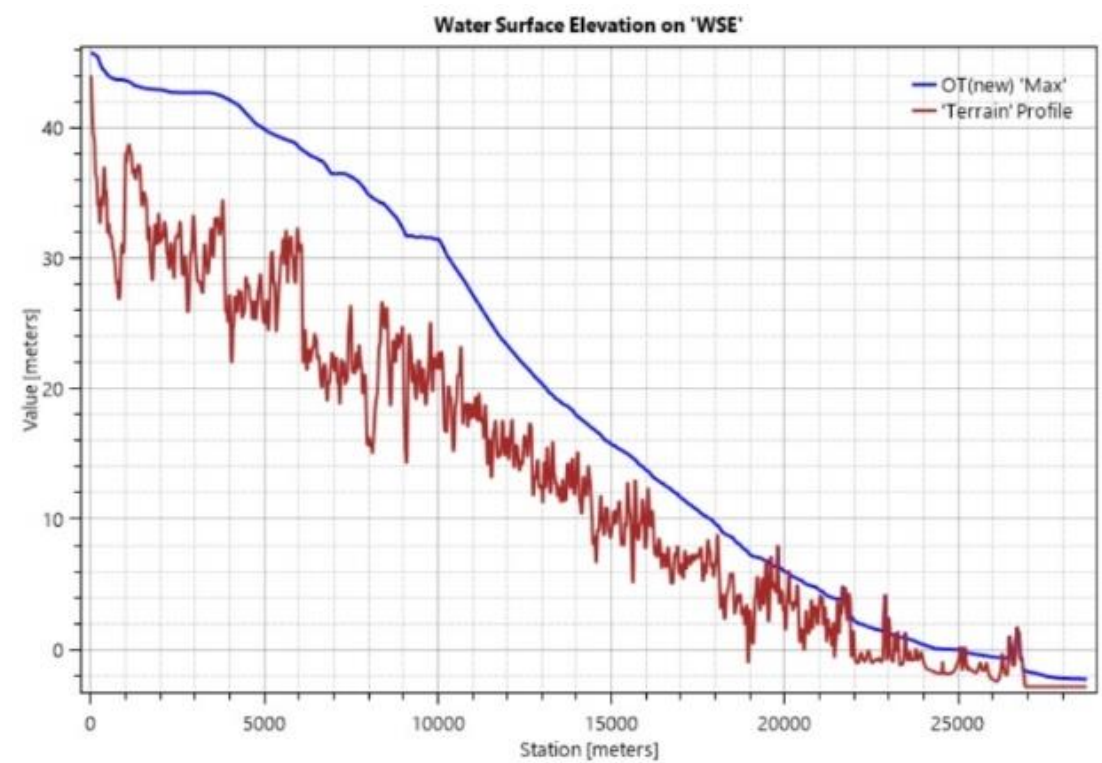

\section{Gambar 5 : Water Storage Elevation (WSE) Sebaran Banjir Akibat Keruntuhan Bendungan Malahayu Kondisi Overtopping.}

Gambar 5 merupakan perbandingan elevasi air dan elevasi tanah pada bagian hilir Bendungan Malahayu. Besarnya kecepatan akibat keruntuhan Bendungan Malahayu dari skenario overtopping merupakan kecepatan paling besar dibandingkan dengan skenario yang lain. Gambar 6 merupakan elevasi air pada bagian hilir bendungan pada masing masing skenario. 


\section{Tabel 5 : Kecepatan Maksimum Akibat Keruntuhan Bendungan Malahayu}

\begin{tabular}{cc}
\hline Kejadian Keruntuhan & $\begin{array}{c}\text { Alur sungai } \\
\text { Kecepatan max } \\
\text { m/d }\end{array}$ \\
\hline \hline Overtopping & 8,685 \\
Piping Atas MAB & 8,292 \\
Piping Tengah MAB & 7,924 \\
Piping Bawah MAB & 8,103 \\
Piping Atas MAN & 8,362 \\
Piping Tengah MAN & 7,864 \\
Piping Bawah MAN & 7,999 \\
\hline
\end{tabular}

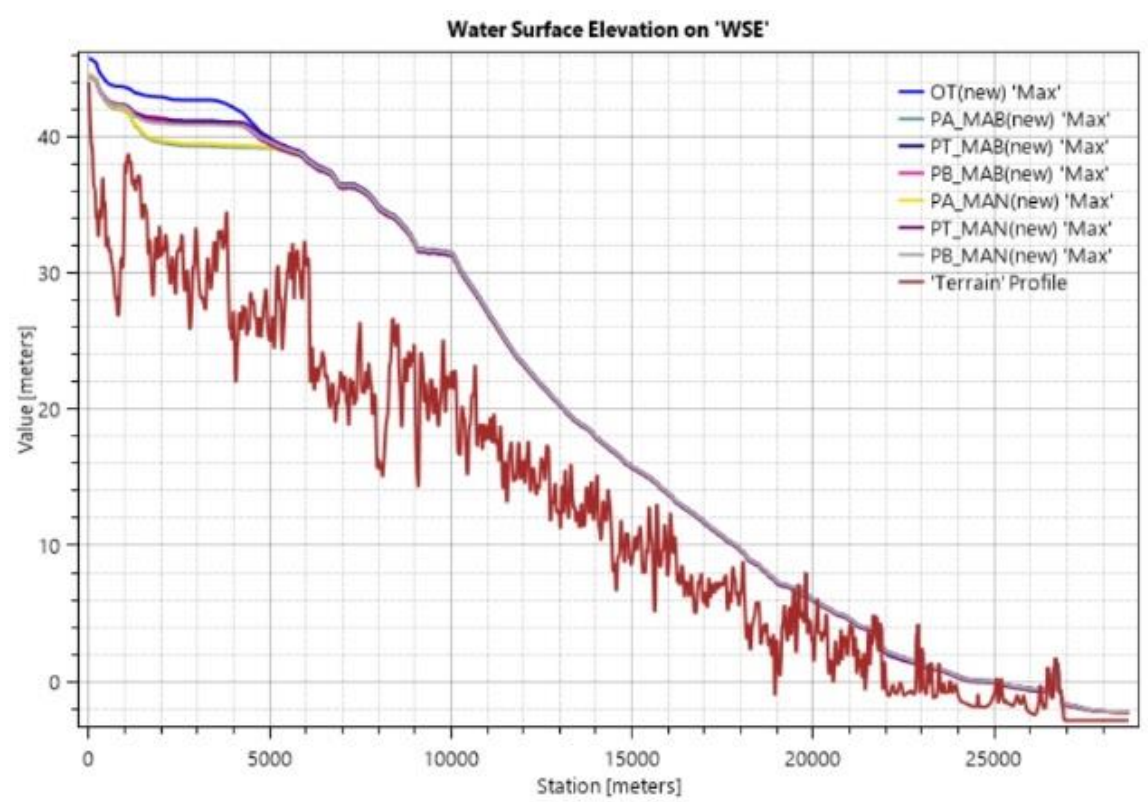

Gambar 6 : Grafik Water Storage Elevation (WSE) akibat Keruntuhan Bendungan Malahayu

\subsection{Klasifikasi Tingkat Bahaya Bendungan}

Dari analisis keruntuhan Bendungan Malahayu yang dilakukan didapatkan total penduduk terkena resiko sebanyak 158767 jiwa, dengan jarak jangkauan banjir 25,60 km. dari jumlah tersebut maka menurut tabel matriks jumlah penduduk terkena resiko dikategorikan sebagai bendungan dengan klasifikasi bahaya tingkat 4 atau sangat tinggi.

\section{Kesimpulam}

Dari hasil analisis yang telah dilakukan serta terhadap simulasi keruntuhan Bendungan Malahayu dapat disimpulkan sebagai berikut:

1. Bendungan Malahayu yang berada di Kabupaten Brebes memiliki potensi curah hujan PMP sebesar $600 \mathrm{~mm}$ dan debit banjir rencana maksimum pada kala ulang 1000 dan PMF masingmasing sebesar $583,324 \mathrm{~m}^{3} /$ det dan $1174,61 \mathrm{~m}^{3} /$ det.

2. luasan dan kedalaman genangan banjir maksimum yang terjadi pada bagian hilir bendungan adalah pada simulasi kondisi overtopping, yaitu masing-masing sebesar 160,32 $\mathrm{km}^{2}$ dan 19,943 m dengan keterangan bahwa kedalaman ini terjadi pada alur sungai di bagian hilir Bendungan Malahayu. 
3. Terdapat 53 desa dengan jumlah 22400 jiwa penduduk terkena resiko akibat keruntuhan Bendungan Malahayu, dengan jarak jangkauan banjir dari bendungan sejauh 25,60 km. maka Bendungan Malahayu termasuk bendungan dengan klasifikasi bahaya tingkat 4 atau bahaya sangat tinggi.

4. Banjir akibat keruntuhan Bendungan Malahayu menyebabkan dampak kerugian terhadap kerusakan bangunan, jalan, tata guna lahan dan kebutuhan minimum penduduk yang mengungsi. Dampak kerugian yang ditanggung penduduk maupun pemerintah setempat akibat keruntuhan Bendungan Malahayu adalah Rp. 515.521.114.788

\section{Daftar Pustaka}

[1] Torimtubun A.T, Asmaranto R, 2018. Analisis Banjir Akibat Keruntuhan Bendungan Banyukuwung Dengan Menggunakan HEC-RAS

[2] CR Rachmadan, Juwono P.T , Asmaranto R, 2010. Analisa keruntuhan benungan alam way ela dengan menggunakan program Zhong xing hy21

[3] Pramono A, Juwono P.T , Asmaranto R, 2019. Analisis banjir akibat keruntuhan bendungan wonorejo dengan menggunakan hec-ras

[4] SNI 2415. 2016. Tata Cara Perhitungan Debit Banjir Rencana. Jakarta: Badan Standardisasi Nasional.

[5] Soewarno. 1995. Hidrologi Aplikasi Metode Statistik untuk Analisa Data. Bandung: Nova

[6] Limantara, Lily M.2010. Hidrologi Praktis. Bandung: Lubuk Agung

[7] Bambang Triatmodjo, 2008. "Hidrologi Terapan". Yogyakarta

[8] US Army Corps of Engineers Hydrolic Engineering Center. 2014. Using HEC-RAS for Dam Break Studies. U.S. Army Corps of Engineers Institute for Water Resources Hydrologic Engineering Center (CEIWR-HEC) 609 Second Street Davis, CA 95616-4687

[9] Departemen Pekerjaan Umum Dirjen Pengairan. 2011. Panduan Perencanaan Bendungan Urugan Volume 2 Analisis Hidrologi. Jakarta.

[10] Asdak,Chay, 2002, Hidrologi Dan Pengelolaan Daerah Aliran Sungai, Gajah Mada University Press, Yogyakarta

[11] Murtiwiyanto. 1988. Metode Perhitungan Penelusuran Banjir. 